\title{
ESTABLISHMENT AND DEVELOPMENT \\ OF ECONOMIC WELFARE THEORY
}

\section{Tomchuk-Ponomarenko Nataliia ${ }^{1}$}

DOI: http://dx.doi.org/10.30525/978-9934-571-28-2_26

Abstract. The article provides analysis of evolution of scientific approaches towards the meaning of the category "living standards of the population" and some methodological aspects of its investigation. Basic research areas of welfare economics in the history of living standards of the population investigation have been determined. The characteristics influencing the research and living standards of the population estimation have been proposed. Logical and historical methods are applied in the article for the purposes of underpinning of primary tendencies of development of welfare economics and living standards, determination of the essence of these categories at current stage; systematic approach meaning the analysis of the target of research is provided on the basis of its organic continuity and simultaneous internal differentiation to relatively independent elements. The latter is possible for the reason that fundamentally any local system is a split whole consisting of not one element but a significant number of differing elements connected with each other the integrity of which conditions the appearance of new integrated features which are not peculiar to severally taken elements comprising the system. The goal of the research is the analysis of scientific approaches towards the essence of social and economic category of "living standards of the population" and some methodological aspects of its investigation by both native and foreign scientists. Realization of the goal conditioned the necessity of solving of the tasks as follows: expound the essence of the "living standards" category and show its interrelation with other synonymic categories; underpin scientific tendencies of welfare theory and living standards of the population development basing on fundamental analysis of the research papers related with the issue of living standards of both native and foreign scientists starting from the times of classic political economy and till present.

\footnotetext{
${ }^{1}$ Candidate of Economic Sciences, Associate Professor at the Department of Economic Theory, Macro- and Microeconomics, Taras Shevchenko National University of Kyiv, Ukraine

(C) Tomchuk-Ponomarenko Nataliia
} 


\section{Tomchuk-Ponomarenko Nataliia}

The above analysis of the history of living standards investigation has been proving its actuality and practical effect for many centuries. The specifity of "living standards" category lies first of all in impossibility of its rendering by any single relation or index. For that reason there exist a burning necessity of structuring the integral system of characteristics and indexes providing overall estimate of the investigated category. Present-day realities of Ukraine encourages to develop a unique concept of living standards, perfection of theoretical and methodological approaches towards its investigation with social-economic, cultural and spiritual differentiations with each particular region taken under consideration.

\section{Introduction}

Active furtherance of rising of living standards of the population, growth of national prosperity is a top-priority task arising and is to be solved by each state the policy of which is oriented towards the implementation of fundamentals of social-oriented market economy development. When determining the current living standards of the population within the state, analyzing its basic structural components, quality characteristics and specific quantity indicators it is necessary to consider the full range of current peculiarities and objectives immanently inherent in the process of growth of both national prosperity in general and living standard of a particular person or family severally. Essentially the category "living standards" unites a wide array of social and economic relations which characterize the peculiarities of living conditions of a person, family, social organizations (social stratums and classes) and also the population of the state as a whole. The uniqueness of the category "living standards" lies in the fact that it can't be rendered by a single index and is objectively determined by a wide range of characteristics, each of which is related to a separate element solely or a certain aspects of relations arising during the process of operation of a single and multifaceted social organism. For that reasons a distinct determination of the essence of the "living standards" category during the research is of prime importance. This precisely is worth attention as far as analysis of the evolution of approaches which is traced in researches concerning deepening of understanding of the "living standards" category at different points of history evidences the availability of rather wide range of approaches. Essentially these approaches differ significantly and sometimes contradict each other that's why determining of a content-related essence of the "living standards" category and underpinning 
of basic directions of welfare economics and living standards is of crucial importance at the time being.

The history of evolution of human civilization suggests that the problems of welfare and rising of living standards were permanent concerns of humanists and scientists. In particular, the above issues concerned the philosophers of ancient times however nothing save for statement of contour of things as at that time, revealing of substantial violation of social justice in the distribution of common weal and drawing attention to escalation of social antagonisms between poor and reach social stratums has been done; real development of theoretical problems of welfare and mechanisms of its support have not been worked out.

\section{Literature Review}

The issue of living standards investigation involved such prominent Soviet and Ukrainian scientists as Abalkin L.I., Bobkov V.N., Kapustin Ye. I., Mayer V.F., Mozhyna N.O., Rabkina M.Ye., Raitsyn V.Ya., Rymashevska N.M., Sygov I.I., Zherebin V.S. and others. Significant contribution into the solution of theoretical and applied aspects on the issues of living standards of the population during the transition period in Ukraine was made by Basyliuk O.V., Boginia D.P., Bondar I.K., Geits V.M., Goleusova G.Z., Danylenko O.I., Dolyshnii A.V., Kvasniuk B.Ie., Kirian T.M., Kolot A.M., Kutsenko V.I., Libanova E.M., Lukinov I.I., Mandybura V.O., Novikov V.M., Onikienko V.V., Pirozhkov S.I., Revenko A.X. and Timofeev V.O. At the same time as at present analysis of scientific approaches of the representatives of different theoretical schools dealing with the issue of welfare, level, quality and value of living of different social stratums and the population of the country in general, estimation of scientific objectiveness of the view the theorists has been kept to and defended, their understanding of the core of social and economic justice and the possibilities for realization and providing of distribution and consumption of the required amount of common weal between different categories, stratums and classes remains to be an important aspect.

\section{Material and method}

Logical and historical methods are applied in the article for the purposes of underpinning of primary tendencies of development of welfare economics and living standards, determination of the essence of these categories 
at current stage; systematic approach meaning the analysis of the target of research is provided on the basis of its organic continuity and simultaneous internal differentiation to relatively independent elements. The latter is possible for the reason that fundamentally any local system is a split whole consisting of not one element but a significant number of differing elements connected with each other the integrity of which conditions the appearance of new integrated features which are not peculiar to severally taken elements comprising the system.

The goal of the research is the analysis of scientific approaches towards the essence of social and economic category of "living standards of the population" and some methodological aspects of its investigation by both native and foreign scientists. Realization of the goal conditioned the necessity of solving of the tasks as follows: expound the essence of the "living standards" category and show its interrelation with other synonymic categories; underpin scientific tendencies of welfare theory and living standards of the population development basing on fundamental analysis of the research papers related with the issue of living standards of both native and foreign scientists starting from the times of classic political economy and till present.

\section{Results}

Real scientific understanding of the wide range of the problems of welfare and rising of living standards of the population, investigation of the issues related to both simple and extended operational force renewal (on personal-family and social levels) in fact was coincident with the period of foundation of capitalistic social and economic formation. At that very period the researches related to the determining of composition, structure and scope of the required social weal which must satisfy the living needs of the population and the estimation of the required sources capable to provide personal-family reproduction at the level of different social groups within society were started. Under the conditions of establishment and development of capitalistic social and economic formation the class structure of society underwent considerable changes as a result of two leading classes formation - the owners of the capital and employers class, primarily consisting of workers (proletarians). After the victory of bourgeois revolution in the majority of European countries the former social class, in addition to economic power, acquired political power thus becoming dominant. 
In the course of development of economic theory of welfare and living standards it is possible to point out political and economic directions as follows: right (liberal democratic), centrtist (social democratic), left (socialistic), estimation and statistical (budgetary-estimative and regulatory-budgetary) and regulatory-economic. They were based on the understanding of basic components of social welfare, issues on ensuring respective living standards for capital owners class and employers class in the course of the defense of their interests in the sphere of final reproductive consumption. Conscious political and economic position of the scientists lied in the following: 1) underpinning of "normality of the existing abnormality" of the circumstances of extreme polarization of living and consumption standards of different social classes, i.e. normality of simultaneous existence of wealth and luxury, poorness and poverty within the society; 2) development of scientific fundamentals of providing of maximum congruence of interests of labor and capital in the sphere of meeting the requirements of final consumption, rising living standards for poor and poverty classes; 3) unconditional critics of the existing major inequality of final social product distribution when on the one part there was a miserable providing of the needs of the reproduction of employed and self-employed labor and on the other part - wealth and luxury of social dominant class living.

The right (liberal democratic) direction coincides with the first half of XIX century which is synchronous with the period of the establishment of classical political economy and foundation of capitalistic relation on the West. Its representatives are U. Petty, F. Quesnay, D. Ricardo and others. The representatives of this concept tried to establish the correlation between the wages amount received and satisfaction of employers' needs; explain the reasons for the differences in the level of the income received and the factors influencing growth of employers' salary. Living standards were treated on both micro- and macrolevel (as a welfare of the nation).

U. Pettirealno The founder of the English classical political economy school, being an irrevocable apologist of the dominant class of capital owners in his "Tractate On Taxes and Dues" underpinned theoretically the mechanisms of settling wages which guaranteed the employer's income providing his living standards on the level satisfying minimal existence requirements (theory of the minimum of funds). The latter he rationalized as follows: "if the employers are paid twice more the minimum determined they will work twice less" [1, p. 21]. The limitation of the theory of min- 
imum of funds lied first of all in the fact that under such conditions not only those needs related to the extension of labor force reproduction could be met but also its simple reproduction failed. Consequently pursuing this approach "historical and moral elements" of the formation of employers" demands were entirely included.

The scientists investigated preferably the efficiency of social support system and its impact on living standards of the population. He outlined the role of a state under the conditions of market economy and the necessity of targeted aid for the purposes of exclusion of dependence and excessive use on the part of the population. "When all helpless and weak people are supported and idlers and criminals are curbed and punished we'll finally find certain permanent engagement for all the rest people who may demand sufficient amount of food and clothes" [2, c. 20].

He also unraveled the impact of taxation of living standards of the population and came to the conclusion the the increase of tax burden results in population welfare deterioration [2, c. 23].

David Ricardo in his work "The Fundamentals of Political Economy and Taxation" approached the problem of wages amount and its adequacy for the satisfaction of employers' needs. "The natural labor cost is that necessary for employers to have the possibility to exist and continue their generations without increase or decrease of their quantity" [2, c. 459]. There were raised the problems of real and nominal salary "The ability of an employee to support his family and himself ... depends not from the amount of money earned as a salary but from the amount of food, items of vital necessity and comfort which became essential for him as a result of getting used to them which are possible to purchase for that money amount" [2 p. 460]. For that reason the inherent value of labor is directly proportional to the price for food and non-consumer goods. Under the conditions of the growth of the prices for food and services the value of labor force increases as well. On the other part the scientist didn't ignore the influence of market mechanism of correlation between the supply and demand.

An outstanding representative of economic thought of England Thomas Malthus (1766-1834) contributed sufficiently into the first concept. Interpreting the poorness as a natural phenomenon he asserted that people must mostly blame themselves in their sufferings. The basic thought of its theoretical concept was that there existed a principal of population the essence of which is "constant striving specific for all living things to multiply faster 
than it is allowed by food amount available" (known geometrical and arithmetical progressions). Denying the philanthropy he asserted that any bounties on the part of the rich, especially monetary, are incapable to eliminate or prevent lower classes poverty. He was convinced that the major and permanent reason for the poorness is little dependent on or independent at all of the mode of government or unequal allocation of property.

T. Malthus as well as D. Ricardo was against "The Laws of Poor" and pointed out that the latter "First, ... stimulate the growth of population without a respective increasing of the amount of consumer goods" Second, the amount of provisions consumed in working houses by the idlers which cannot be treated as useful social units decreases the share of people which are more useful for the society by the share consumed" [2]. T. Malthus saw the role of the state in taking various preventive measures for the purposes of establishment of such a correlation between the population and the means for its existence which would not "result in struggle between them" [2].

The theory of "harmony of interests" of basic classes of capitalistic society became a crucial concept of the right-liberal apologetics. The founder of this theory is deemed to be Claude Frederic Bastiat (1801-1850). The scientist, in his opinion, phrased the main question: are the interests of people, left on their own, in harmony with each other or are they directly opposed to each other? F. Bastiat determined market economy as the world of will and harmony, economic freedom and mutual cooperation of different classes. Pursuing the theory of economic harmony by F. Bastiat, the interests of labor and capital are associated. He overemphasized the ideas of economic liberalism and free competition principles. Defending social inequality as coercion in respect of people unwilling to work F. Batistat was convinced by permanent meddling the government twists labor relations and remuneration for it, interfere with the principles of industry and exchange, misleads capitals and labour forces and causes unprecedented waste of human resources.

The development of "harmony of interests" conception was furthered by the representative of the USA economic thought of XIX century Henry Charles Carey (1793-1879). He asserted that capitalism creates the conditions for economic growth and sustainable development of the society. The researcher outlined that along with bourgeois society development due to the growth of the efficiency of labor productivity and growth of capital the share of employers in national product grows both absolutely and relatively 


\section{Tomchuk-Ponomarenko Nataliia}

and the share of capitalists while increasing absolutely decreases relatively. "Out of all the principles established by the science - as H.C. Carey wrotethis is the most brilliant principle for the operation of this principle lies in the harmony of true interests of different classes of human society" [3].

Francois Quesnay (1694-1774) a founder of French physiocrats school should be pointed out. He investigated real sources of the growth of living standards of the population. He created the concept of the necessity of "equal exchange of goods" where he proved: exchange of trade does not generate wealth; nothing is produced in the process of exchange".

The latter he explained that in the sphere of exchange under the conditions of free competition an equivalent exchange of equal value inherent in goods prior to their entering a market takes place and concluded: in the course of exchange material wealth as the source of living in not created that's why profit appears [4, c. 48].

Consequently, the investigation of the right concept can't be treated as multi-method research for it concerned only separate aspects of understanding of living standards. The burning social problems as of that time were such as sufficiency of wages received, state support for needy families, factors of national welfare growth, underpinning of the role of the state in public relations regulation.

The second centrists (social democratic) concept changes the accents from political and economic to economical and statistical concept of analytical assessment of living standards; moving from macro- to microlevel of economic welfare theory investigation takes place. Attention is focused on the issues of living standards determining, real living value of working population in particular and consequently establishment of the required salary amount with the consideration of branch and regional distinctions.

The founder of the centrists, social democratic, concept of economic welfare theory may be deemed a classic of the English political economy Adam Smith (1723-1790). Smith was engaged with the problem of widening of poorness phenomenon within working class and thought that "a human must have a possibility to exist with the help of its labor and his salary must be at least sufficient for his existence" [5 p. 64]. He determined the reasons for the differentiation of employers pursuing their wages amount, the primary among which were: pleasantness or annoyance of work; simplicity and cheapness or complexity and expensiveness of acquiring the needed expertise; permanent or casual employment; bigger or less trust 
given to those persons engaged in certain business; probability or impossibility of success in activity. Analyzing the factors determining the level of wages he outlined the immaturity of the theory of living minimum wage rationalizing that this is the lowest standard barely compatible with basic humanism. He established the ground for understanding of social justice asserting that "undoubtedly, no society can't flourish and be happy in case its major part is poor and miserable. Moreover, simple justice requires that people who provide food, clothes and build dwelling for the entire nation receive the share of their own labor product allowing them to have deserved food, clothes and dwelling themselves" [5, p. 64].

To the representatives of centrists' conception in political-economic welfare theory we can also refer the theorists of social reformism as follows: E. Bernstein, O. Bauer, K, Kautsky, R. Hilferding.The main topic of their programs of social-democratic reformations were the issues of rising of living standards and welfare of the population including working classes of social sector, equitable distribution of social product among all the members of society etc.

To the prominent investigators of this concept we can refer V. Pareto, A. Marshall, A. Pigou and others. Thus, in his work "Political Economy Textook" (edition of the year 1906) V. Pareto basing on the analysis of statistic data deducted the principal of profits allocation ("the principal of Pareto") which expresses the dependence of living standards of the population on the amount of income and the number of the receivers. Starting out from "social heterogeneity" based on "physical, moral and intellectual" inequality of people the scientist stated that "this inequality which is inherent in human being is met by economical and social inequality" [6, p. 273]. In this way, in the scientist's opinion, the society returns to the type of income allocation specific for it. The major part of income is accumulated by the majority of population while high income make insignificant share of national income. He saw the problem of poorness first of all in the lack of production. The best way to improve the situation of poor classes of the population is to arrange for the wealth grow faster than population and the basis of state income must become taxation of the income of the majority and not the big incomes.

A. Marshall deepening theoretical investigation analyses the issue of financial support of the growth of living standards of the population through the perspective of differential approach towards the evaluation of 


\section{Tomchuk-Ponomarenko Nataliia}

the amount of personal savings and determining the best regimes of temporary limitation of consumer levels of any given population stratum. In the work "Principles of economic science" he focused on the investigation of the mechanism of the allocation of wealth between current consumption and suspended conditions of the use of monetary incomes of population and also clarifying of motivation towards "curb" of current consumption of the population for the sake of funds accumulation which are designated for the purposes of economic growth in future. A. Marshall asserts that one of the conditions forcing people to cut their current consumption and stimulating the accumulation of savings is family relationships. This is due to the fact that people work and save monetary funds mainly for the purposes of rising of living standards of their families and not their personal welfare [7, p. 201].

The successor of A. Marshall is A. Pigou who developed neoclassical ideas, underpinning of the concept of economic welfare and factors influencing it. Thinking over the problematics of researches the scientist made an accent on the feasibility of economic science which sphere of interests must be determined by practical needs of society. The science must provide applicable instrumentarium for the growth of citizen's welfare. He consciously restricted his own research by "the frames of the sphere of social welfare within which it is possible to directly or indirectly apply a measuring scale with the help of money" [8, p. 73-74] which he named economical welfare. The scientist accented that the notion of personal welfare is not limited by the sole economic aspect and includes such indexes of quality of living as conditions of environment, labor and recreation, availability of education, public order, medical treatment etc. Economical welfare of the society the researcher explained by the amount of national dividend (the share of material income which may be expressed in money) and the way of its allocation between the members of the society. He was among the first who paid attention to the imperfection of national income index for economical welfare determining.

In this way at the given stage of interpreting of living standards statistic methods were deepened and furthered, basic principles of consumer behavior as a result of the growth (deterioration) of the living standards of population were formed and the research gained practicability.

The founder of the left (social) concept of political and economical welfare theory is Karl Marx. In his works economical and social aspect of the 
category "living standards" and "welfare" gained deep theoretical underpinning. Thus in "The Capital" the author mentioned: "Working class, in order to maintain its usual living standards must obtain at least former amount of the needed means of subsistence, although it may be also changed in respect of the nature of goods it is comprised of..."[9]. K. Marx treated "living standards" as a social and economic theory which specified the level of satisfaction of physical, spiritual and social needs of people. Thus characterizing "traditional living standards" he pointed out that this level provides not only satisfaction of physical needs and also satisfaction of those needs derived from social conditions people exist and are educated in. Analyzing the functioning of the pattern of labor work force value determining he was the first scientist who underpinned that it "includes historical and moral elements". The scientist underpinned inevitable alienation of work and its results under the conditions of capitalism where exploitation rises not from individual, casual situation of market exchange but is a result of the very logics of capitalistic unequal appropriation. K. Marx directed his economic research to the underpinning of the conclusions about the inevitability of perishing of capitalistic social-economical formation the first motivating force of which is economic fear (competition) and the second is economic voracity (i.e. aiming for unlimited appropriation of profits). He focused his attention on the analysis of antagonistic social-class contradictions and social conflicts their extrapolation for revolutionary future of the humanity, underpinned the tendency of constant absolute and relevant deterioration of working class living standards; he considered proletariat itself to be the tomb of the capitalism.

Theoretical interpretation of the issues of living standards of the population by contemporary left radicals considerably differs from its interpretation from the positions of market liberalism theory which is entertained by neoclassicists. Thus the radicals criticize traditional theories of common weal as inhuman by nature for their chasing unlimited consumption destroy moral values, ignore harmonious personal development and do not further the solution of the problems of mankind humanism-based development. Denying traditional welfare theories R. Edwards and others state that the new theory must be based first of all on the refusal of market rationalism inherent in capitalistic society. The main focus at solving the problem of social welfare must be paid to inclusive development of a person, its consciousness, perfection of the structure of needs and advantages in consumption. 


\section{Tomchuk-Ponomarenko Nataliia}

Evaluation-statistical concept of economical welfare theory focuses attention on the issues of living standards and welfare of the most economically wretched and socially vulnerable groups of the population. An important constituent part of this theoretical concept lies in comparison of incomes and expenditures of the poor population stratums with incomes and expenses of the rich socially dominant classes and determining of the coefficients of social-economical differentiation.

Historical development of the society at the given stage resulted in the necessity of working out a theoretical basis for scientific evaluation of real living value which was crucial for the reproduction of labor potential and providing of material sources for reproduction of the needy stratums of population. This concept was based on the determining of specific set of weal - market basket of consumer goods which were developed on the basis of respective composition and structure required for the satisfaction of living needs for a person or a family at tolerance level.

The analysis proves that evaluation-statistical concept of economical welfare theory development is divided into budgetary-evaluating (ascertaining-statistical) and normative-budgetary. Budgetary-evaluating aims at practical realization of the two basic and mutually related tasks. The first task lies in the evaluation of the welfare level of social stratums by reference to statistically recorded amounts of actual consumption of consumer and non-consumer goods pursuing the established composition and structure, determining of the composition and structure of consumption most unique to the families of different levels of income and social status (the level of monetary and natural incomes, number of family members, level of household naturality, impact of ethnic-national and moral-religious factors on the consumption etc.). The second task lies in engagement and practical use of the given household budgets in general system of economic-statistical analysis of local economies for the purposes of investigation of complex social and economical mass processes through them: differentiation of households pursuing production and consumption volume, estimation of dynamics and volumes of property and monetary households accumulation; share of the population pursuing consumption level, income and property; determining of the standards of purchasing activity of the families with different levels of income and their impact on market demand and proposition etc. The first steps of budgetary-statistical analysis of welfare of the population in Europe were made by 
Gregory King (1648-1712) who in his work "Natural and Political Observations and Conclusions on Terms and Conditions in England" (1696) paid much attention to the analysis of average incomes and expenditures of the families belonging to different social classes.

Similar nature had budgetary researches of Joseph Massie (1711-1784), the English economist who in his work "Calculation of Year Taxes for the Families of Different Social Status and Class" (1756) along with the analysis of the level of prices for consumer goods and trade condition in England he endeavored to clarify the meaning of indirect taxes for the budgets of nobility, merchants, landowners and municipal and village workers.

Aurthor Young (1741-1820) - English economist and politician investigated living standards of agricultural workers, analyzed the reasons for their poverty relying on self-developed approximate budget for the family consisting of spouses and three children. AS the basis of his work he used data of four budgets of really existing farm laborers families.

In 1795 appeared a big work of Irish canon Davis David (1741-1719) "Consumer Basket of Farm Workers in Different Part of the Kingdom". The work included investigation of the budgets of more than one hundred households which were united in groups in accordance with the program preliminary developed with the help of questionnaires structured in advance. At this the author thoroughly and fundamentally investigated the reasons for existing poverty seated in restricted possibility to satisfy even minimum requirements of people. This very work is considered to be the beginning of the entire epoch of extended budget investigations aiming at investigation of living standards, requirements and the rate of their satisfaction within wretched, mostly marginal population stratums.

Further historical analysis of budgetary statistics development included the investigation of the works by Friedrich Morton Eden "The Standing of the Poor or the History of English Workers" (1797). The momentum for the writing of the book by F. Eden was famine of 1794-1795 which revealed extreme poverty of hired farm workers (farm servants). Basing on the assistance of parishes the researcher collected 73 budgets of farm workers pursuing detailed plan and thoroughly processed those data in compliance with the established by him classification of needs estimated according to 12 articles of budgetary expenses. The works by F. Eden, I. Dukpesio "Budgetary Economy of Classes of Belgium" (1855), Le Play "Working Population of Europe" (1855) and others showed extreme poverty of country peo- 


\section{Tomchuk-Ponomarenko Nataliia}

ple and farm workers, arouse active disputes within society and furthered the establishment of the International partnership for the investigation of social-economic practice which aimed at continuing budget investigations and publishing of their results in "The Two Worlds Workers" magazine. The works became classic scientific achievements which were of great importance for further development of statistical-evaluating or budget-consumer concept of economic welfare theory.

Only in the end of XIX the beginning of XX century active researches which gave rise to normative-budget concept began. The primary task of this concept lied in creation and perfection of the necessary methodological approaches and development of methodologies allowing delivering respective calculations of the cost of consumer baskets. Such consumer baskets by their composition and structure had to meet minimal living standards the representatives of hired workers, and base of their formation was objective necessity for providing of work force renewal and reproduction.

It is possible to assert that the development of normative-budget concept is explained by the emergence of the burning need of rising of the level or representativity of determining of real living cost of working population and consequently establishment of the required wages amount (taking into account branch and local peculiarities and differentiations) in compliance with the needs of the process of work force reproduction. The above was implemented for the purposes of reduction of social tension, restriction of the potential for escalation of social antagonisms and conflicts which in the beginning of XX century began to extremely negatively influence the stand of social stability and dynamics of economic development of society.

The next concept which may be pointed out as a separate within the framework of economical welfare theory and living standards is normative-economical. In the economic science of the West it investigates the issues of market economic efficiency and social attractiveness of alternative economical solutions, defines the ways of increasing of social usefulness and was named "welfare economy". Normative-economical concept was considerably developed after World War II for its principles were often declared as an important constituent part of the politics of governments of countries with developed capitalistic economy which competed with socialistic system including that concerning population welfare gain. The development of this concept has two streams. The first stream is related to the games theory and starts from the appearance of the work by J. von 
Neumann and O. Morgenstern "The games theory and economic behavior" and is treated as an instrument of the investigation of economic behavior, social cooperation and strategic analysis. The second stream appears on the basis of the theory of collective choice and individual estimations which allows investigating aggregation of the politics with economic decisions. The peculiarities of this stream lie in the follows: 1) it avoids the investigation of relations, processes and phenomena occurring in the sphere of final consumption economics i.e. that final stage of social reproduction where the completeness of satisfaction of objective existential needs and full development of the human personality (family, social stratums and the entire population) is provided; 2) it scarcely investigates the existing levels of people differentiation according to their needs and does not determine the ways and mechanisms of overcoming poorness and poverty and respective limitation of wealth and luxury; 3 ) its increased focus is on the analysis of hypothetic macrodependencies determining the Pareto efficiency depending upon the following the pattern of utilitarian possibilities, applying of the principles of compensation and variants of choice between economic efficiency and social justice and also investigates market failures in solving the problems of welfare and possibilities of the influence of the state on the elimination of negative market externalities which bar welfare gain; has no distinct developed welfare criteria (cost-natural borders of extended reproduction) in respect of an individual, family, social group, class or the entire society. Thus, normative-budget concept relates the essence of its scope of research with making of decisions basing mostly on value judgments and relates to what must be in difference from positive economy which gives an opportunity to give scientific credence to the functioning of economy and relates to what exists or what may exist.

Consequently, during the second half of XIX century till the 20s of XX century the main focus in "living standards" investigation was on the extension of its interpretation, determining the factors causing inequality of the material welfare of people, the issue of poverty reduction. The researches became more practical each year.

Starting from the following period and up to nowadays the scientists continued the perfection of researches definitions and directed them into more social-oriented framework. Along with "living standards" category appeared such as "poverty rate", "wage rates", "unemployment rate", "way of living", "quality of living", "development of humanity" etc. 
The middle of the XX century was marked by the appearance of the living quality concept which underpinned that economic welfare gain of the population does not result in social, moral and spiritual growth. The most precise definition of the term "quality of living" nowadays is given by I.V. Gukalova. Quality of living is the category characterizing the living conditions and the stand of population in the specific environment from the point of view of its capability of providing reproduction and sustainable society development. This is territory-specific social-environmental-economic efficiency of the realization of needs the main of which is the need for sustaining of life and health [12].

In the early 80 s the ideas of quality of living concept provided the basic human development concept. Its foundation was determined by the strengthening of social orientation of economic development in advanced countries on the one part and by the problems of inequality of the countries of the world - on the other part. This resulted in the understanding that development characteristics may be not only traditional macroeconomic indexes, GDP amount in particular and income per head of population. In the above concept personal development is determined as not only as the achieved level of welfare but also as the process of personal possibilities growth - a person has to live a long life, be healthy, educated, use political and economic freedom, human rights and social respect towards personality.

Ukrainian scientists of that time made their contribution into the theoretical study of "living standards" category. They suggested treating the definition of "living standards" category in the narrow and broad sense. In the narrow sense living standards is determined by the level of satisfaction of personal needs and respective level of personal income providing personal consumption. In the broad sense it is the characteristic of social and economic stand of life of population and is determined by the actual level of consumption of material, spiritual and social weal and services, level of satisfaction of rational (intellectual) needs. At the same time there appeared the first regional theoretic-methodological researches of living standards of the population of the state. A concept of living standards of the population was also developed what promoted inclusive development of all the members of the society.

A number of outstanding scientists of the Institution of social-economic problems of the population RAS headed by N.M. Rimashevska considered the widest category to be "welfare of the population" which generalizes 
"conditions", "level", "way" and "quality of living". Consequently Soviet scientists provided a clear definition of "living standards" category, deepened theoretic-methodological aspect of its investigation, completed it with the synonymic definitions which are widely applied nowadays. Within Ukrainian scientific circles the most popular are the researches concerning living standards of the population although this branch still remains insufficiently investigated. The majority of the researches reflect different social economic aspects of transformations mostly at the state level. Investigated are the phenomena of poverty, analysed are incomes and expenses, property differentiation and the issues of the determining of middle class criteria. The problems of living standards are only began to be investigated. At present among the modern Ukrainian researches prevails the approach towards living standards in the narrow and broad sense. Thus, O. Bogutsky suggests differentiating the category in the narrow sense - in order to refer to personal needs of people solely; in broad sense - actual level of consumption of material, spiritual and social weal and services, level of intellectual needs satisfaction etc. Personal needs are one of the basic categories in the process of living standards analysis which differ a personality from others in physical, intellectual and social aspects. The sources of their satisfaction are incomes of society [10, c. 43]. V. O. Mandybura treats living standards in broad sense as "... the totality of relations and conditions determining life, labor, living and intellectual-cultural personal development, characterizes the level of satisfaction of various needs of population achieved in the society for a certain period of time (not only physical but also social, intellectual and spiritual) and also determines and estimates real economic sources and social-legal warranties of population activity" [11, p. 18]. In the researcher's opinion this category is relative as far as depends not only on the level of real income and consumption and also on the extent of the development of needs themselves. In other words, the dynamic of living standards is determined. It is also specified that living standards is a multilevel category with its own structure where the three basic levels are outlined: integrated, social differentiated and individual-personalized (or family). Challenging is the idea of F.B. Uzunov who suggests that living standards of the population is qualitative and quantitative characteristics of the level of achievements, human life component. From O.G. Topchiev's perspective living standards of the population are the main component-wise specifications of activity conditions. I. V. Gukalova under the notion of "living standards" means the 


\section{Tomchuk-Ponomarenko Nataliia}

scope of realization of the needs of population which appear to be the basic unit of measurement [12]. O.Iu. Miroshnychenko asserts that at present living standards is a multicomponent social-economic category with complex interior structure the essence of which is not limited to material living conditions. According to the results of research-methodological development in respect of living standards of the population development the author suggested classification of the factors influencing living standards of the population comprised of six groups: economic, social-political, social-legal, intellectual-cultural, environmental-climatic and historical [13].

Consequently living standards of the population is one of the most complex social economic categories explaining the existence of its different interpretations: from philosophic-worldview including statistical. The major characteristics influencing the investigation of living standards are as follows: 1) dynamism of the category; 2) wide and narrow interpretation; 3 ) outlining of macro- and microlevel of researches; 4) individual and social load of the category; 5) satisfaction of certain category of needs of the population (material or spiritual); 6) taking into account objectives differences in living standards of the population as a result of labor application in different spheres of economic activity and regional development differentiations [14].

\section{Conclusions}

1. The above analysis of the history of living standards investigation has been proving its actuality and practical effect for many centuries. The specifity of "living standards" category lies first of all in impossibility of its rendering by any single relation or index. For that reason there exist a burning necessity of structuring the integral system of characteristics and indexes providing overall estimate of the investigated category. Present-day realities of Ukraine encourages to develop a unique concept of living standards, perfection of theoretical and methodological approaches towards its investigation with social-economic, cultural and spiritual differentiations with each particular region taken under consideration.

2. The state social policy, aimed at raising the standard of living of all segments of the population, should be connected with such tasks of stable economic development as ensuring real growth of production, improvement of the situation on the national labor market, containment of inflation processes, effective use of budget funds and means of special extrabudgetary funds. It is the effective macroeconomic development that provides the 
foundation for the country's social development and ultimately determines the level of well-being of its population.

3. The most important direction of the social and economic policy of the government and the state should be the achievement of a stable positive dynamics of the welfare of the population on the basis of increased demand for money, the development of a system of social standards that would really ensure a decent standard of living for the population and meet European standards, and its implementation should include gradual stages of achievement these standards for several years separately for each category of the population.

\section{References:}

1. Petty U. (1940). Ekonomicheskiye i statisticheskiye raboty. M.: Socekgyz, pp. 70-71. (in Russian)

2. Anthology of Economical Classics: V. Petti, A. Smith, D. Ricardo / Sost., Aut. prelude IA Joiners - Moscow: Ekonov,: Key, 1993. P. 475. (in Russian)

3. Keri G. CH. Rukovodstvo $\mathrm{k}$ sotsial'noy nauke. per. $\mathrm{s}$ angl. kn. L. N. Shakhovskoy. - Sankt-Peterburg: Izdaniye kn. Shakhovskogo, 1869. P. 704. (in Russian)

4. Kene F. (2008). Selected economic works. Moscow, Sotsekgiz. P. 1198. (in Russian)

5. Smith A. (2001). The Wealth of Nations. An Inquiry into the Nature and Causes of the Wealth of Nations. - K.: Port-Royal. P. 594. (in Ukrainian)

6. Pareto V. (1999). Manuale di economia politica (Book of Political Economy). - Ural LTD, P. 273.

7. Marshall A. (1993). Principles of Economics - M.: Progress, vol. 2, p. 219. (in Russian)

8. Pigou A. (1985). Economics of Welfare. - M.: Progress, vol. 1. pp. 73-74. (in Russian)

9. Marx K. (1963). Kapital. Capital. T.1 - K.: State Publishing House of Political Literature of USSR, pp. 23-26. (in Ukrainian)

10. Bogutskiy O. (1998). Analysis of socio-economic category of living standards of Ukraine // Ukraine: aspects of work. - no. 2. - pp. 43-47. (in Ukrainian)

11. Mandybura V. (1998). The living standards of Ukraine and problems of reforming the mechanisms of its regulation / D. P. Bohynya (executive editor). - K.: Parliamentary publisher, P. 255. (in Ukrainian)

12. Gukalova I. (2009). Yakist zhyttya naselennya Ukrayiny: suspilno-geografichna konceptualizaciya. Monografija - K., pp. 77-81. (in Ukrainian)

13. Miroshnychenko O. (2008). Statystychne ocinyuvannyja rivnya zhyttya naselennya: avtoref. dis. kand. ekon. nauk: 08.00.10 / O.Yu. Miroshnychenko. - K., pp. 1-5. (in Ukrainian)

14. Riven zhyttya naselennya Ukrayiny (2006). NAN Ukrayiny. In-t demografiyi ta soc. doslidzh., Derzh. kom. statystyky Ukrayiny; Za red. L.M. Cherenko. - K.: TOV "Vydavnytstvo "Konsultant", 2006, pp. 1-8. (in Ukrainian) 